\title{
Growth in containership sizes to be stopped?
}

\author{
Ulrich Malchow
}

\author{
Bremen University of Applied Sciences, Bremen, Germany and \\ Port Feeder Barge, Hamburg, Germany
}

\begin{abstract}
Purpose - The increase of containership sizes driven by the need to create greater economies of scale seems to be an endless process. Vessels of more than 21,000 TEU are presently on order. The purpose of this paper is to question whether a positive effect still remains at present mega ship sizes and, even if this was the case, whether such presumably small effect would be outweighed by costly operational impacts for the lines and the ports out of the huge ship sizes.
\end{abstract}

Design/methodology/approach - The effect of increasing ship sizes on the three major cost items in container shipping have been investigated by extrapolating founded regression curves, applying respective physical laws and referring lumpsum crewing cost (as the major part of the vessel's running costs) to various ship sizes.

Findings - In this paper, it is shown that further effects of lower slot costs lessen while ships get larger. Hence, a further increase in ship sizes would not significantly reduce transport costs anymore. In contrast, the necessary efforts to prepare the ports for ships of ever-increasing size are growing over proportionally with every additional metre of draught and/or beam. It is shown that an ongoing increase of containership sizes, e.g. in the Europe-Far East trade, does not bring any further benefit, neither for the ports and their terminals nor even for the lines itself and not even for the shippers! It is an amazing mechanism that all stakeholders act rationally on their own, but the overall effect for all of them (including the public) has turned into negative.

Originality/value - The results may pave the way for a closer cooperation among ports, e.g. within the Hamburg-Le Havre range. Ports and terminals may see the opportunity to escape the spiral of ongoing efforts for deepening and widening the fairways and installing ever-bigger gantry cranes by agreeing on a joint policy with regard to maximum ship size.

Keywords Economies of scale, Maersk, Mega ships, Slot costs, Ultra large container ships

Paper type Research paper

\section{Purpose}

The stunning growth of container ship sizes which is shown in Figure 1 is only powered by the economies of scale (EoS) effect. It is the purpose of this paper to question whether a positive effect still remains at present mega ship sizes and, even if this was the case, whether such effects would be outweighed by costly operational impacts for the lines out of the huge ship sizes.

From Figure 1, it can be derived that since the second half of the 1990s, industry leader Maersk Line has led and fuelled the ship size development which other carriers apparently felt forced to follow and in the recent past have even surpassed the industry leader. With the only two exceptions of the jumbo vessels of later bankrupt US lines for its round the world

(C) Pacific Star Group Education Foundation

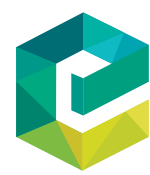

Received 23 January 2017

Revised 16 June 2017

Accepted 10 July 2017 


\section{MABR}

2,3

\section{0}

Figure 1.

Record breaking ship sizes and their initiators

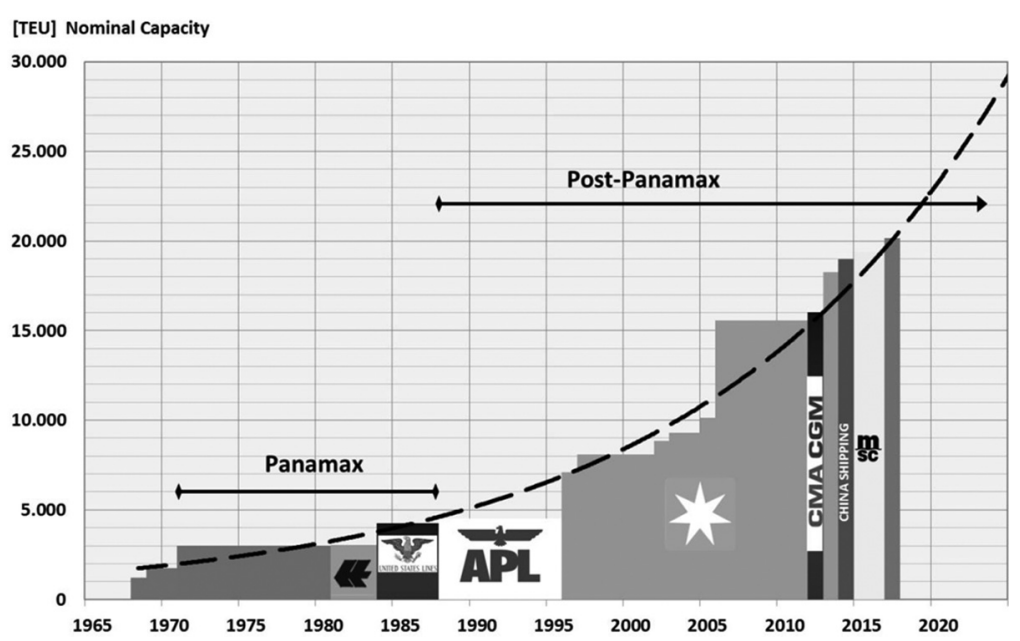

service in the late 1980s and the first Post-Panamax vessels of APL for trading across the Pacific in the early 1990s, all record breaking box ships have been introduced in the EuropeFar East trade for the past 40 years.

If the future development still followed the exponential regression curve which describes the growth until now very well, we would see the first 23,000 TEU vessel around the year 2020, and vessels of 30,000 TEU could be expected from 2025 onwards. As this size would correspond with approximately $20 \mathrm{~m}$ draught, it should be the ultimate limit for the time being due to the depth of the Malacca Strait.

While it was believed that Maersk's "Triple-E-Class" ships of 18,270 TEU would mark a record of some validity, other carriers have come up with orders for further record-breaking vessels. Consequently, the question is evident how far we are actually following the path up to 30,000 TEU?

It is the tanker sector which could act as a case to prove that size limits in shipping do exist and have been already experienced. Decades ago, tanker sizes had reached more than 500,000 dwt, with only two vessels of that size built which do not exist anymore. The present maximum tanker sizes are much smaller.

\section{Approach}

When intending to make use out of the EoS effect by putting ever bigger container vessels into service, container lines are aiming for a reduction of three major specific cost items:

(1) investment per TEU;

(2) fuel costs per TEU; and

(3) operating costs (mainly for crewing) per TEU.

The effect of increasing ship sizes on these cost items have been investigated by extrapolating determined regression curves, applying respective physical laws and referring lumpsum crewing cost to a bandwidth of ship sizes. 


\subsection{Investment per TEU}

Ironically it has to be accepted that actual shipyard prices (per TEU) are not a well-suited indicator for the size dependence of the specific investment (per TEU). Many recently delivered mega vessels were even in absolute terms significantly less costly than similar or even smaller ships delivered just before. This is because the actual shipyard price is not only determined by the vessel's size but also to a great extend influenced by the situation in the shipbuilding market, prices for steel and labour, exchange rates, number of vessels ordered and even the negotiation skills of the parties involved, etc.

To exclude such influences, shipbuilding has to be treated as what it is: floating steelworks. Hence, the pure number of processed tons of steel would be a good indicator for size-related investment efforts (especially with bigger containerships whose investment is not so much influenced by engineering and outfitting). As the pure steel weights remain mostly a secret of the shipyards and the contracted design offices, the light displacement shall be used as a meaningful indicator (according to the Archimedes law the light displacement equals to the total light ship weight). Beside the steel weight, it also comprises the significant weight of the propulsion plant which in all cases is consisting out of twostroke-slow-speed-engines with a consistent power/weight ratio within the relevant power range. That is why, the sum of both weights is qualified with sufficient accuracy to be used as a meaningful indicator to describe the investment efforts for the entire vessel.

Figure 2 shows the specific light and full displacement per TEU of a number of recent new buildings in the range from 3,000 to 20,000 TEU and the extrapolation of their regression lines up to 30,000 TEU. It is quite obvious that the specific investment effort is getting less with increasing ship size. Both curves are of asymptotic shape, i.e. they are getting flatter with increasing ship size. From 4,000 to 8,000 TEU, the specific investment per TEU (expressed by the specific light weight) is substantially reduced by 15 per cent. However, the same step from 14,000 to 18,000 TEU results only in 5 per cent reduction. Interestingly, the specific full displacement which also comprises the specific deadweight is diminishing at a significantly higher rate, i.e. also the specific deadweight per TEU (as the distance between both lines) is getting less the bigger the ships become. Hence, each additional TEU provided by increased ship size not only loses more and more of its cost advantage but also is getting less valuable in terms of utilisable deadweight.

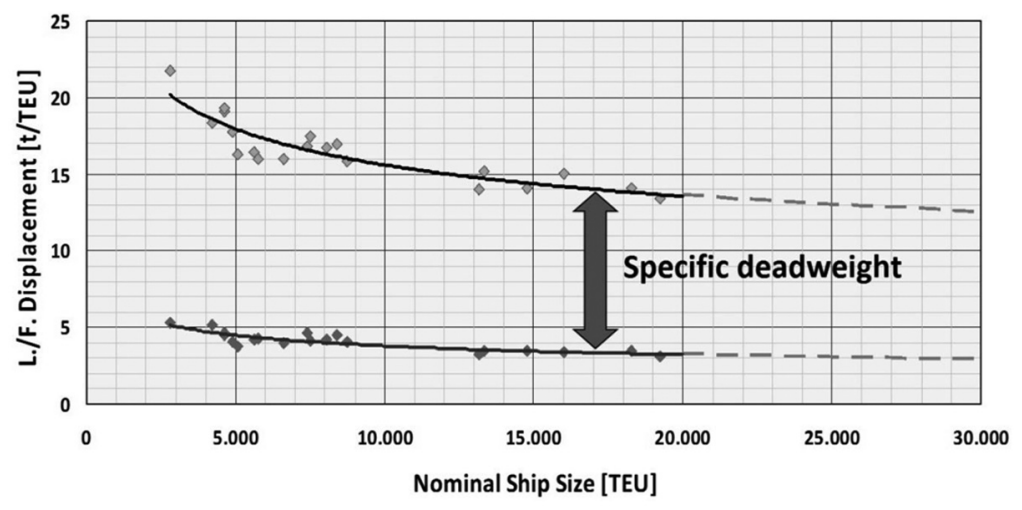

Source: Capacity plans of various ships

Figure 2. Specific full/light displacement 
MABR

2,3

202

\subsection{Fuel costs per TEU}

Fuel costs are directly proportional to the fuel consumption which in turn is directly proportional to the propulsion power (within a certain bandwidth around the design engine load). At any given constant speed, the specific propulsion power per TEU is decreasing with the ship size according to the famous admiralty formula used by naval architects [equation (1)]. It is illustrated in Figure 3 that for any given speed (specific propulsion power expressed as a percentage of the value for a 1,000 TEU vessel), the related curve is generally also of asymptotic shape. A vessel of 5,000 TEU causes only 80 per cent of specific fuel costs [US\$/TEU] compared to a 1,000 TEU vessel. However, the big step to (still) hypothetical 30,000 TEU vessels would certainly further reduce the specific fuel costs, but they would be still significantly more than 60 per cent of the 1,000 TEU level. Hence, despite the big step in size, the advantage of this decisive cost item is getting drastically less.

\subsection{Crewing costs per TEU}

The biggest cost item within the operating expenses is crewing costs. As they are in principle independent from the ship size (for vessels bigger than approximately 1,000 TEU), the specific costs per TEU are getting naturally less with increasing ship sizes. The resulting curve for a fixed crewing bill per vessel is consequently also of asymptotic shape (Figure 4). The step from a 4,000 to 8,000 TEU vessel would naturally cut the specific crewing bill per TEU by half (e.g. by US\$190/TEU). However, the same step from 14,000 to 18,000 TEU leads to a further reduction of only 22 per cent, whereas the related base is much lower in fact. Hence, further savings in absolute terms are only US\$24/TEU.

\section{Findings}

3.1 Summary on slot costs

All three curves of the decisive "effort parameters" per TEU (light displacement, propulsion power, crewing costs) are of asymptotic shape. Hence in principle, the impact of the general EoS effect is getting weaker the bigger the ships become. At the present mega ship sizes the effect of any further potential increase was only marginal!

Nevertheless, Maersk is stating that the slot costs of the Triple-E-Class (18,270 TEU) are US\$500/TEU less compared to vessels of 14,000 TEU (presumably referring to its own E-Class). Indeed, by comparing both ship generations which are shown in Table I alone, a

Figure 3.

Specific propulsion power (at any constant speed)

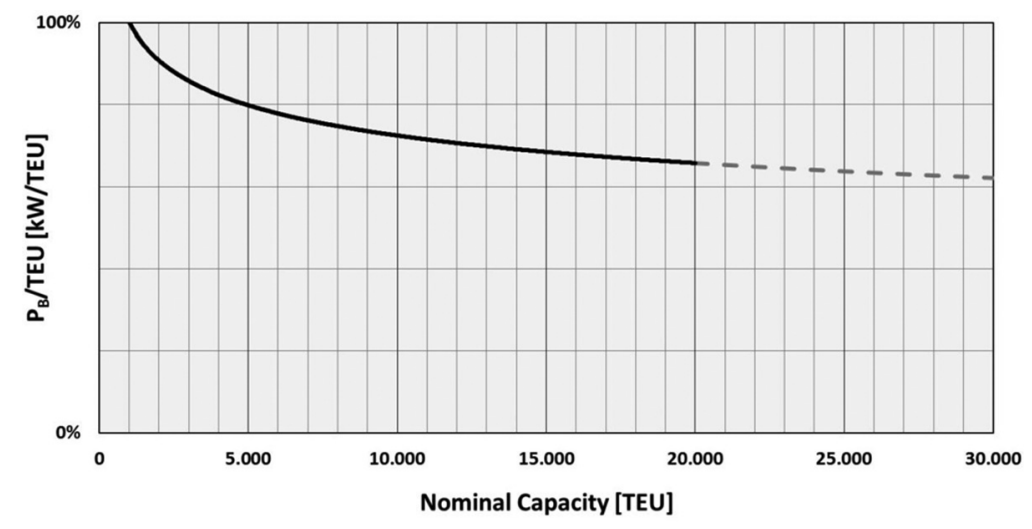

Source: Author's calculation 


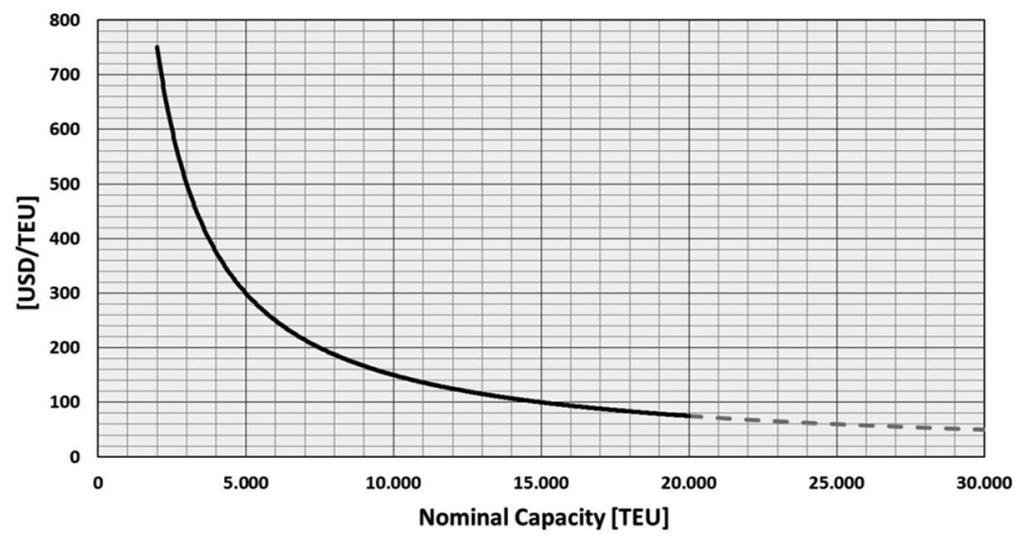

Growth in containership sizes

203

Source: Author's calculation

Figure 4.

Specific crewing costs (at e.g. US $\$ 1,500,000 /$

\begin{tabular}{lllll}
\hline & E-class & Triple-E-class & & \\
\hline Year built & 2006 & 2013 & & \\
Capacity & $14,770 \mathrm{TEU}$ & $18,270 \mathrm{TEU}$ & $+24 \%$ & \\
Full displacement & $208,000 \mathrm{t}$ & $258,000 \mathrm{t}$ & $+24 \%$ & \\
Deadweight & $156,907 \mathrm{t}$ & $194,000 \mathrm{t}$ & $+24 \%$ & \\
Propulsion power & $80,080 \mathrm{~kW}$ & $59,360 \mathrm{~kW}$ & $-26 \%$ & \\
Top speed & $26 \mathrm{knots}$ & $23 \mathrm{knots}$ & $-12 \%$ & $-7 \%$ by EoS \\
Spec. propulsion power & $5.42 \mathrm{~kW} /$ TEU & $3.25 \mathrm{~kW} / \mathrm{TEU}$ & $-40 \%$ & $-33 \%$ by speed
\end{tabular}

Source: Maersk/author's calculation

Table I.

Comparison of containership generations

tremendous reduction of 40 per cent in specific power demand per TEU (which is proportional to the fuel consumption per TEU) is obvious at first glance.

However, a calculation based on the admiralty formula [equation (1)] reveals that only 7 per cent out of these savings in specific propulsion power per full displacement $[\mathrm{kW} / \mathrm{t}]$ are a result of the EoS effect [equation (3)]! The remaining is simply a consequence of the reduced speed (and increased engine efficiency). As with these ships, the TEU capacity has increased at the same rate as the full displacement; the assertion is also valid for the specific propulsion power per TEU [kW/TEU][equation (4)]:

$$
\begin{gathered}
P=\frac{\Delta^{\frac{2}{3}} v^{3}}{C} \\
\frac{P}{\Delta}=\frac{\Delta^{-\frac{1}{3}} v^{3}}{C}
\end{gathered}
$$




\section{MABR}

2,3

\section{4}

$$
\begin{gathered}
\frac{\frac{P_{E E E}}{\frac{\Delta_{E E E}}{P_{E}}}}{\Delta_{E}}=\left(\frac{\Delta_{E E E}}{\Delta_{E}}\right)^{-\frac{1}{3}}=0.93 \\
\left.\frac{P_{E E E}}{\frac{P_{E E E}}{T E U_{E}}} \frac{\left(\frac{T E U_{E E E}}{T E U_{E}}\right.}{T E U_{E}}\right)^{-\frac{1}{3}}=0.93
\end{gathered}
$$

$\mathrm{P} \quad=$ Propulsion power $[\mathrm{kW}]$

$\Delta \quad=$ Full displacement of vessel $[\mathrm{t}]$

$\mathrm{v} \quad=$ Speed of vessel $[\mathrm{m} / \mathrm{s}]$

$\mathrm{C}=$ Admiralty constant

$\mathrm{TEU}=$ Nominal container capacity

Indices:

E: Maersk's “E-Class” (e.g. M/V. "Emma Mærsk”, 14,770 TEU)

EEE: Maersk's “Triple-E-Class” (e.g. M/V. “Mærsk Mc-Kinney Møller”, 18,270 TEU)

One precondition of successfully making use of the EoS effect is that the ship utilisation does not drop. Otherwise the effect turns into its opposite anyhow, and the costs per (used) slot are getting higher with bigger vessels. DNV-GL has made some evident calculations taking a 14,000 TEU vessel as a base. The overall slots costs could be reduced by 11 per cent by stepping to 21,000 TEU, provided the utilisation rate remains unchanged (with 100 per cent) as shown in Table II.

Meanwhile, reality has shown that utilisation could not be kept at required high levels. As the massive ordering of especially mega vessels has naturally heavily contributed to global overcapacity the general fleet utilisation has necessarily fallen, i.e. there is not any cost advantage left at all!

Overcapacity in any pure price-driven market such as liner shipping, in which only the cost leader is generally ahead of the competition, results immediately in a price slump. In today's cutthroat competition the required high ship utilisation has to be paid for in terms of freight rebates. Hence, it cannot get worse. The imaginary initial but actually not existing cost advantage per TEU of the latest new buildings is more than eaten up by lowered freight rates caused by poorer utilisation rates - an inevitable consequence of the oversupply provided by such mega vessels. The cost advantage is just handed over to the line's customers, who certainly appreciate such gifts without being really dependant on such windfall rebates.

\begin{tabular}{lcccc}
\hline \multicolumn{5}{c}{ Vessel size } \\
Utilisation (\%) & $14,000 \mathrm{TEU}(\%)$ & $16,000 \mathrm{TEU}(\%)$ & $18,000 \mathrm{TEU}(\%)$ & $21,000 \mathrm{TEU}(\%)$ \\
\hline 100 & 100 & 97 & 91 & 89 \\
95 & 105 & 101 & 96 & 94 \\
90 & 110 & 106 & 101 & 98 \\
85 & 117 & 112 & 106 & 103 \\
80 & 123 & 119 & 112 & 116 \\
75 & 131 & 126 & 119 & \\
Source: DNV-GL (2014) & & & &
\end{tabular}

Table II.

Impact of size and utilisation on slot costs

:DNV-GL (2014) 
Such rebates however do not present a significant reduction of total freight costs as the pure pier-to-pier costs of container shipments accounts only for 20-30 per cent of the total costs of the entire door-to-door transport chain. The impact on the retail price could be, if any, only a few cents. Hence, a further increase in ship sizes does not stimulate any additional shipments as it was the case at the beginning of containerisation when the reduction in freight costs (compared to break bulk shipments) actually generated additional demand for cargo shipments. Hence, the oversupply remains and ever lower freight rates do naturally not improve the profitability of the lines.

At the same time, a lot of still-young vessels of 8,000 to 10,000 TEU size are replaced by bigger vessels and have massively lost value as they are simply too small (and also too fast) for today's east-west trunk routes. Consequently, they are shifted into trades where they can supersede smaller vessels. This cascading continues into all trades and classes of ship sizes and contributes to overcapacity everywhere.

In addition, as loading/discharging rates do not keep pace with ship size development, the mega ships stay more time in port, i.e. forcing the lines to increase the speed during the sea voyage to avoid an increased duration of each round voyage. Hence, contrary to the idea of the EoS increased ship sizes actually contribute also to higher fuel consumption! That is why the lines are continuously pressing their terminal partners to implement the latest technology to speed up ship-to-shore container handling.

Drewry has shown that port productivity in terms of berth moves per day cannot keep pace with the increase of ship size as per Table III even if the same crane handling rate (independently of ship size) is assumed as the number of gantry cranes cannot be increased proportionally with the increase of container capacity (due to the cubic law). However, author's calculations have shown that also the average load cycle time with a 19,000 TEU vessel is approximately 40 per cent higher compared to a 5,000 TEU vessel just due to the longer distances each container has to travel (assuming the same crane). Hence, contrary to the assumption of Drewry the handling rate of cranes cannot be taken as constant but have to be reduced for bigger ships. Assuming that the rate drops only by 20 per cent to 20 moves/h, the 19,000 TEU vessel stays more than half a day longer in port as calculated by Drewry. Compared with a 7,000 TEU vessel such vessel has 171 per cent more capacity and stays actually 71 per cent more time in port (last line of Table III)! All measures taken in the past to increase the handling rates of cranes especially for bigger ships do certainly also apply for smaller ships.

Despite the introduction of ever smarter technologies for faster ship-to-shore container handling (e.g. 4-TEU-spreader, two-trolley-cranes, dual cycle crane operation), it must be conceded that quite a portion of the progress which has been made in the past in ship-toshore container handling productivity is just a windfall profit, i.e. being a result of the increased TEU factor (TEU/number of containers) in global container trade! This is a fact which is being widely ignored. The port of Hamburg has experienced an increase of its TEU factor from 1.32 to 1.64 during the past 25 years as per Figure 5 . In 1990, 76 moves by gantry

\begin{tabular}{lcccccccr}
\hline Ship size & $\begin{array}{c}\text { Containers } \\
\text { exchanged } \\
\text { per port call }\end{array}$ & $\begin{array}{c}\text { No. of gantry } \\
\text { cranes } \\
\text { deployed }\end{array}$ & $\begin{array}{c}\text { Crane moves } \\
\text { per hour }\end{array}$ & $\begin{array}{c}\text { Berth } \\
\text { moves } \\
\text { per hour }\end{array}$ & $\begin{array}{c}\text { Berth } \\
\text { moves } \\
\text { per day }\end{array}$ & $\begin{array}{c}\text { Total cargo } \\
\text { handling } \\
\text { time [days] }\end{array}$ & $\begin{array}{c}\text { Ship size } \\
\text { increase } \\
(\%)\end{array}$ & $\begin{array}{c}\text { Port } \\
\text { productivity } \\
\text { increase }(\%)\end{array}$ \\
\hline 7,000 & 2,800 & 3 & 25 & 75 & 1,650 & 1.7 & & \\
13,000 & 5,250 & 5 & 25 & 125 & 2,750 & 1.9 & 86 & 67 \\
19,000 & 7,700 & 6 & 25 & 150 & 3,300 & 2.3 & 171 & 100 \\
19,000 & 7,700 & 6 & 20 & 120 & 2,640 & 2.9 & 171 & 60
\end{tabular}

Source: Drewry Maritime Research (2014)/author's calculation Growth in
containership
sizes

205

$-2$ 
MABR

2,3

\section{6}

Figure 5.

TEU-factor in the Port of Hamburg

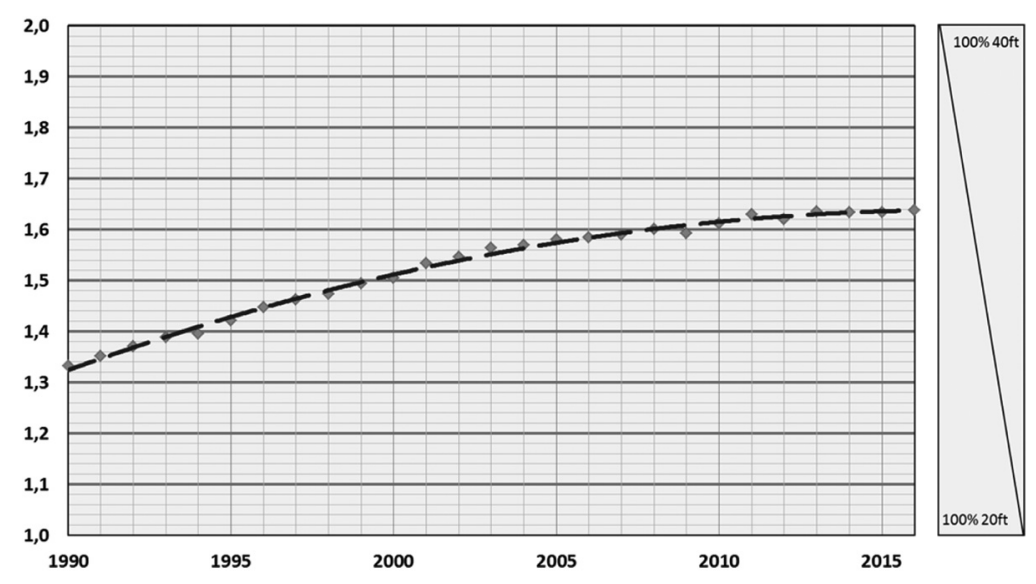

Source: Port of Hamburg Marketing Board

crane were needed to handle 100 TEU, whereas only 61 moves were still required for the same box volume in 2015. Hence, a productivity gain of 24 per cent has just been a result out of the changing cargo structure and is by no means caused by any terminal efforts to accelerate container handling! It appears that the TEU factor (at least in Hamburg) is following (with an almost perfect regression) an asymptotic shape and apparently has just reached its maximum. Hence, no further productivity gains can be expected in the future as a "gift" from the cargo structure anymore.

Meanwhile, it must be concluded that even for the container lines itself as the driving force behind the development towards ever bigger vessels the envisaged positive effects on slots costs have turned into the negative. At a fixed round voyage duration the fuel costs per slot increases with longer port stays as the speed has to be increased for compensation and lower utilisation rates caused by the huge overcapacity provided by the mega vessels contribute to higher actual slot costs which have to be covered by even lower freight rates.

\subsection{Impact on ports}

Indeed, in response to the bigger vessels, ports are making continuous efforts to prepare for the latest generation of mega ships. This is a complete change of the game compared to the times of break bulk liners in the past which were designed to meet the specific needs of their particular trading area, i.e. mainly to the restrictions of the ports of call. As containerisation has made ports more exchangeable, today it only takes the announcement of a new generation of ships to cause ports to make immediate investments to meet the needs of these bigger ships.

The ports are continuously adapting their facilities in a pre-emptive obedience due to the fierce competition among them. From the individual port's view, this procedure was justified in the past. Since the start of containerisation, the growth in ship sizes has reduced the costs per slot, leaving space for continuous downward freight adjustments. Hence, the ports have heavily benefited from the resulting cargo boom. Also, from the global economic perspective, all investments in ports to accommodate ever bigger vessels have made sense, as this has fostered the worldwide division of labour and therefore contributed to the increase of worldwide wealth - not just in the developed world. While in the future the 
worldwide container traffic is still expected to grow, it will not be induced by reduced slot costs any more but just by the general global economic parameters.

In the meantime, it has been already widely addressed that increasing ship sizes introduced by the lines to get their benefit out of the EoS effect do provide a lot of costly challenges to port authorities and terminal operators. The necessary efforts to prepare the ports for ships of ever-increasing size are growing with every additional meter of draught and/or beam not only in initial dredging but also in keeping such depth. Ports have to adjust fairways, harbour basins and quay walls to allow the installation of ever larger and faster gantry cranes at costs which are increasing more than proportionally with the ship size, whereas the actual cost advantage for the lines out of the increased ship sizes tends to become negligible as shown in Figure 6 - if not turns into negative. This has made the relationship between mostly publicly financed efforts to develop port infrastructure and the related overall economic returns increasingly unfavourable.

Public resources are being spent just to allow those container lines that can afford to invest in such megaships to have a theoretical cost advantage over their competitors. Therefore, it is the public sector that bears a major portion of the costs of such competition. Could it be even called a distortion of competition in favour of the very big lines that is sponsored by the public? At least it can be stated that one party of the intermodal transport chain is optimising its processes at the cost of all the other parties. However, actual benefits are not to be expected.

The situation for the ports is getting even worse as the liner shipping industry continuously tends to consolidate through take overs, mergers, insolvencies and creation of operational alliances. In the meantime, the number of major alliances has been reduced to only three (2M, Ocean Alliance, THE Alliance) as per Table IV. They are handling approximately 90 per cent of the entire global east-west container trade and have nevertheless gained approval from all relevant anti-trust authorities with respect to their customers.

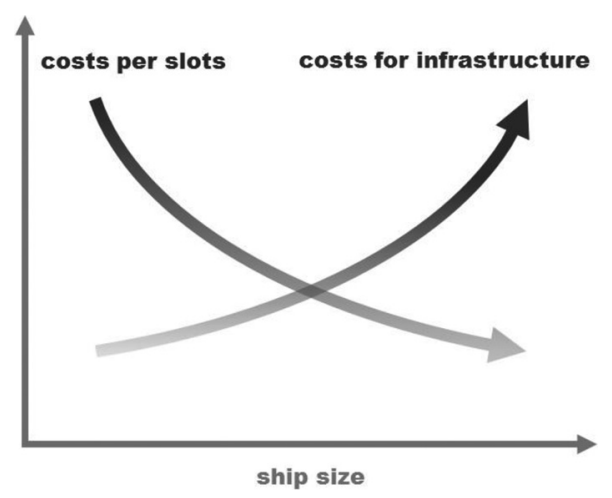

Figure 6.

Contrary effects of ship size development

\begin{tabular}{ll}
\hline Name & Members \\
\hline $2 \mathrm{M}$ & Maersk, MSC (associated: HMM) \\
Ocean Alliance & CMA-CGM, COSCO-China Shipping, Evergreen, OOCL \\
THE Alliance & Hapag-Lloyd (incl. UASC), K-Line, MOL, NYK, Yang Ming \\
\hline
\end{tabular}

Table IV.

Major container line alliances 
MABR

2,3

However, the ports and their terminals are very much dependant from joint operational decisions taken by these alliances with regard to ports of call, actual berth/terminal choice, vessel size and sailing frequency. This kind of market power towards the port and the terminal industry has presumably not been considered in the course of the anti-trust approval.

Those behind this process, which does not bring any sustainable advantage to any of the involved parties, are the big container lines. The ports act as facilitators to the cutthroat competition among the lines by providing the preconditions for increasing sizes. Ports that do not adapt their facilities to the needs of the big vessels will lose mainline business, which will be followed by missing feeder volumes. Understandably, ports are eager to avoid getting involved in such a downward spiral.

While the additional costs of adapting the suprastructure and infrastructure are burdened by terminal operators and port authorities (i.e. mostly by the public) no additional revenue out of the big vessels is gained as the total number of shipped containers is not influenced by the size of the carrying vessels (any more). Sometimes it is even just the opposite. Some port authorities grant rebates in harbour dues for mega vessels just to keep them calling or to possibly compensate any "inconvenience" in the course of their nautical approach.

Hence, nobody is actually benefiting (except three Korean shipyards, some upcoming Chinese ones, four Belgian and Dutch dredging companies and one dominating Chinese gantry crane manufacturer). It is a tragic mechanism which has turned into a global "loselose-lose-situation" for ports, terminals and the lines itself. Even the shippers, being not really dependant on the lowest possible freight rates of today, do not benefit any more but are heavily suffering from the operational shortcomings in terms of delays caused by extreme peak loads at the terminals which have never been experienced before.

Although the development has been initiated by the lines (obviously by Maersk in particular and followed by the rest of the industry), it is unlikely that they are able to stop it by themselves. The supposed cost cutting potential by the specious EoS effect and the fear of supposed cost advantages in favour of the competitors is apparently too tempting to be ignored and accurate calculations which integrate all impacts of ship size development to all stakeholders are too complex. No single line has the standing to withstand the temptation. Even Evergreen, whose founder and chairman was a long standing but lonely believer in smaller vessels and independency, has recently drastically changed its policy after the death of Chang Yung-fa by ordering mega vessels in the course of joining at first the former CKYHE alliance (now being part of the new Ocean Alliance). Apparently, the industry, even in today's consolidated condition, cannot escape by its own initiative from this vicious circle but may need some help from outside.

\section{Options for setting limits}

Assuming that there are no technical limits ship sizes will most probably grow to 30,000 TEU unless measures are taken from outside to escape the useless spiral. Possibly even the lines would feel relieved, as they would be freed from the compulsion to invest in ever-bigger vessels in ever shorter intervals. Following institutions could set a limit:

\subsection{Insurers}

Insurers are increasingly concerned about the huge cluster risks connected with the operation of mega container ships. The total loss of one of such vessel and its cargo could easily cause a damage of US\$1 to $2 \mathrm{bn}$ (including salvage costs). In their own interest, a size limit could be set, e.g. by denying insurance cover for such big cluster risks or a drastically 
raised premium for mega ships to destroy any theoretical cost advantage out of their operation.

\subsection{Suez canal}

As all mega ships are at first introduced in the Europe-Far East trade, the passage of the Suez Canal has to be considered. With present nautical restrictions, the canal allows for vessels of up to approximately 22,000 TEU size. However, the canal has just been upgraded. Transit time has been shortened from 18 to $11 \mathrm{~h}$ and capacity has been increased to 97 transits up from the earlier 47 ships per day. In the course of the extension, also the depth has been increased. Once the depth is adapted over the full length of the canal the present draught limitations could be adapted accordingly (possibly to $20 \mathrm{~m}$ ) - paving the way for vessels of up to 30,000 TEU. Hence, the Suez Canal Authority (2015) could play a key role with regard to the limitation of ship sizes! Ever bigger ships mean that less ships will pass the canal. Consequently, the canal authority should refrain from any action to lift the restrictions in their own interest.

\subsection{Ports}

Ports which for the time being are all fighting (and suffering) on their own and consider the draught as one of their decisive criteria in competition could take the chance by stepping into more cooperation among the port industry by setting a joint size limit. Such limit would affect firstly the Europe-Far East trade as the biggest vessels have always been introduced here. As there is much overlapping in their hinterland and their number is relatively small the ports of the Hamburg-Le Havre range are strategically most suited to set such limit on the European side, as a limit at one end of the trading area would be naturally sufficient. These few ports (except Rotterdam for obvious reasons) could play a strategic role in finally limiting container ship sizes on a global scale - not just to their own benefit!

\section{Conclusion}

The development of container ship sizes has reached a level that does not bring any benefit to the container lines any more, whereas other stakeholders of the transport chain are suffering from the consequences in terms of additional investment (ports, terminals) or operational shortcomings (shippers). It is a tragic and global "lose-lose-lose situation".

However, the container shipping industry is apparently not able to escape from this useless spiral of growth by its own. With the current draught and beam limits of the Suez Canal approximately 22,000 TEU is the present size limit, which will be most probably reached very soon. However, the recent expansion of the Suez Canal would allow to increase its beam and draught limitations (to $20 \mathrm{~m}$ ). Hence, ship sizes could grow up to 30,000 TEU (Malaccamax) unless limiting measures are taken from outside.

There are only three stakeholders in the game which can stop the spiral of growth. Beside the Suez Canal Authority (2015), only a joint action of some strategic ports could stop the ever-increasing ship sizes. North European ports are predestined to play a key role in introducing size limits, as there are less ports on the western end of the Europe-Far East trade which in addition have quite some overlapping hinterland than on the eastern side. Hence, only a few strategic ports in Europe would be needed to set a global size limit for container ships, as the biggest ships are always introduced in the Europe-Far East trade. Rotterdam would certainly not take part in such joint action but would continue to advertise its facilities suited to virtually any ship size. However, ships which in Northern Europe could only call at Rotterdam would be commercially too risky to operate (similar to the $500,000+$ dwt tankers of the 1970s). Such measure should be supported by insurers asking
Growth in containership sizes

209 
MABR

2,3

\section{0}

for unattractive premiums to cover the huge cluster risks related to ships bigger than 22,000 TEU.

In view of the enormous private and public funds that become necessary to construct and accommodate the ever-bigger vessels without any sustainable benefit for none of all parties involved, it is worth to consider the meaningfulness of size limiting measures in terms of practical and political feasibility.

\section{Reference}

Suez Canal Authority (2015), available at: www.suezcanal.gov.eg (accessed November 2015).

\section{Further reading}

American Retail Shippers Association (2017), available at: https:/americanretailshippers.com/ category/alliance/ (accessed 22 May 2017).

Baker, J. (2015), “Canal expansion offers bright future for Egypt”, Lloyd's List, 14 September.

Cullinane, K. and Khanna, M. (1999), "Economies of scale in large container ships”, Journal of Transport Economics and Policy, pp. 185-207.

Cullinane, K. and Khanna, M. (2000), "Economies of scale in large containerships: optimal size and geographical implications", Journal of Transport Geography, Vol. 8 No. 3, pp. 181-195.

Grønvald Raun, K. (2015), “These are the OECD's recommendations for mega-ships”, ShippingWatch, 2 June.

Malchow, U. (2014a), "Should ports take action to stop lines going for ever-bigger ships", Containerisation International, December, pp. 63-64.

Malchow, U. (2014b), “Größenwachstum von Containerschiffen - Eine Kritische Reflexion”, HANSA, July, pp. 40-43.

Malchow, U. (2015b), "The curse of the economies of scale, Containerisation International", October, pp. $40-42$.

Malchow, U. (2015b), “Der Fluch der 'Economies of Scale”, HANSA, August, pp. 30-33.

Merk, O. (2015), "The impact of Mega-Ships”, OECD-Report.

NN (2015a), "Evergreen commits to ULCCs", World Cargo News, February.

NN (2015b), "Who will pay for a port productivity revolution?”, Container Insight Weekly, Week 12, Drewry Maritime Research.

Probst, J.-O. (2014), "Developments of large container ships - what are the limits?", Container Ship Update, DNV-GL.

Stopford, M. (2002), "Is the drive for ever bigger containerships irresistible?", Proceedings of the Lloyds List Shipping Forecasting Conference, 26 April.

\section{Corresponding author}

Ulrich Malchow can be contacted at: malchow@portfeederbarge.de

For instructions on how to order reprints of this article, please visit our website: 